\title{
Perceptions of medical students regarding educational climate at different phases of medical training in a Malaysian medical school
}

\author{
Muhamad Saiful Bahri Yusoff ${ }^{1}$, Rogayah Ja'afar ${ }^{1}$, Hafiza Arzuman ${ }^{1}$, Wan Nor Arifin ${ }^{2}$, \\ Mohamad Najib Mat Pa ${ }^{1}$. \\ ${ }^{1}$ Medical Education Department, and ${ }^{2}$ Biostatistics \& Research Methodology Unit, School of Medical \\ Sciences, Universiti Sains Malaysia, Kubang Kerian, Kelantan, Malaysia.
}

\section{ARTICLE INFO}

Received

Accepted

$: 13 / 01 / 2013$

Published

: 24/03/2013

: 01/09/2013

\section{KEYWORD}

Educational climate

DREEM

Medical school

Curriculum review

Medical student

\section{ABSTRACT}

Introduction: Medical and allied health educators around the globe agreed that an optimal educational climate is a vital aspect for effective learning to take place. Without a doubt, appraisal of the educational climate has been emphasized as a key to the delivery of high quality medical education. In addition, the appraisal provides useful feedback to particular institution to improve their curriculum. Objective: This study was employed as part of the School of Medical Sciences (SMS) Universiti Sains Malaysia curriculum review process. It aimed to explore the strengths and weaknesses of the current medical curriculum thus could provide useful information to guide the curriculum review committee during the review process. Method: A cross sectional study was conducted on a total of 656 medical students from the first, third and fifth year of study. Purposive sampling method was applied. DREEM was administered to the medical students to evaluate the educational climate in the studied medical school. Result: A total of 511 (77.9\%) medical students completely responded to the 50 statements of DREEM. The mean global score across phases of medical training was $128.36 / 200$. The global scores for year 1 , year 3 and year 5 were $138.94 / 200,122.27 / 200$ and 125.49/200 respectively. Results showed that; 1) the medical school had reasonably level of educational climates across phases of medical training; 2) the medical teachers were knowledgeable and well prepared for the teaching; 3 ) the students were overloaded with factual knowledge; 4) the medical teachers were quite harsh to students during teaching session especially in clinical phase; 5) students experienced a significant amount of stress that led to poor memory; 6) the learning process was inclined toward teacher-centered rather than student-centered learning; 7) students had a considerable healthy social relationships with peers as well as others; and 8) academic dishonesty became more apparent in the clinical phase. Conclusion: The medical school's educational environment across different phases of study was more positive than negative. However, there are plenty of rooms for improvement as perceived by the medical students. The medical school should address various important issues highlighted in this article during the curriculum review process.

(C) Medical Education Department, School of Medical Sciences, Universiti Sains Malaysia. All rights reserved.

CORRESPONDING AUTHOR: Dr Muhamad Saiful Bahri Yusoff, Medical Education Department, School of Medical Sciences, Universiti Sains Malaysia, Kubang Kerian, Kelantan, Malaysia. Email: msaiful@kb.usm.my 


\section{Introduction}

Medical and allied health educators around the globe agreed that an optimal educational climate is a vital aspect for effective learning to take place (1-5). Likewise, a favourable educational climate has favourable impacts on students' professional development, academic completion and personal well-being (4-8).Without a doubt, appraisal of the educational climate has been emphasized as a key to the delivery of high quality medical education (1-5).

Over the past 15 years, medical and allied health educators in various educational settings across the world have widely used the Dundee Ready Educational Environment Measure (DREEM) to appraise their institutions' educational climate (3, 8-16). This valuable tool was originally designed in English (13) and has been translated into various languages such as Swedish, Greek and Spanish (17-19). These papers have shown that DREEM is internationally accepted as a useful tool to provide feedback on strengths and weaknesses of the educational climate at particular educational institutions. One of the most important implications of DREEM is that it provides a standardized way for international comparisons between medical schools as well as allowing them to benchmark their educational climate $(3,15,16,20)$. Likewise, it may locate areas of concern shared by the majority of students that might be unintentionally neglected by educators $(3,15,16)$.

For the last 15 years, literature showed that the global score of DREEM across different educational settings (i.e. UK, Canada, Australia, Malaysia, Turkey, Nepal, India, Nigeria, Saudi Arabia, Chile, Sri Lanka, Trinidad and Yemen) ranged between 89 and 143 out of $200(8,9,11$, $12,14,21-35)$. Specifically, the global score of DREEM perceived by medical students at the clinical phase across institutions (i.e. Saudi Arabia, India, Trinidad, Turkey, Australia, Sri Lanka, Chile, Malaysia and Nigeria) ranged between 86.4 and 143 (22-31). Likewise, the total score of DREEM perceived by medical students at the pre-clinical phase across institutions (i.e. Saudi Arabia, India, Turkey, Sri
Lanka, and Nepal) ranged between 96.5 and 130 (24, 26-29). In addition, the total score of DREEM perceived by medical students at the para-clinical phase (i.e. the transitional phase to clinical years whereby the basic sciences and clinical clerkship subjects are integrated) at two institutions in Sri Lanka and Malaysia ranged between 109.7 and 117.9 (8, 26). Despite variation of the reported findings between institutions and phases of medical training, these facts demonstrated the ability of DREEM to appraise a particular institution's strengths and weaknesses as well as to make comparative analyses of student's perceptions between different educational setups (31).

This study was employed as part of the School of Medical Sciences (SMS), Universiti Sains Malaysia curriculum review process. It aimed to explore the strengths and weaknesses of the current medical curriculum thus providing useful information to guide the curriculum review committee during the evaluation process. This study was designed to answer 5 questions which include 1) What is the overall education climate in the medical school? 2) What is the educational climate status at different stages of medical training in the medical school? 3) What are the common areas of concern shared by the different stages of medical training? 4) What are the specific areas of concern at each stage of medical training? 5) What are the recommendations that could be derived from these results?

\section{Method}

A cross sectional study was conducted and purposive sampling method was applied. The researcher selected first, third and fifth year medical students (i.e. a total number of 656) in the School of Medical Sciences, Universiti Sains Malaysia as study subjects. The first, third and fifth year of study were selected due to it will represent the different phases of medical training which were pre-clinical, para-clinical and clinical. This study was approved by the medical school for its curriculum review process.

The medical school provides a self-directed, problem-based, integrated, community-oriented 
and spiral medical curriculum (36-39). This five year programme is divided into three phases. Phase I (year 1) is the fundamental year focusing on basic sciences subjects through the organbased systems. Phase II (years 2 and 3) is the para-clinical phase, which is a transitional phase to clinical years that continues the systems-based approach and introduces the basics of clinical clerkship. The major learning method in the Phase II is problem-based learning (PBL). Phase III (years 4 and 5) is the clinical phase whereby the students are rotated through all the clinical disciplines.

Data was collected by a guided self-administered questionnaire during a face-to-face session in a hall. Completion of the DREEM inventory was voluntary and the medical students were informed that failure to return the inventory would not affect their progress in the medical course. The forms were immediately collected after they were completely filled in. Data was analysed by Statistical Package for Social Sciences (SPSS) version 20. A descriptive analysis of the collected data was done.

The DREEM inventory was developed as a tool to measure educational climate $(13,40)$ and was claimed as a 'cultural-free' instrument (40). There are 50 items measuring five aspects of educational environment based on students' perception which include students' perception of learning (SPoL), students' perception of teaching (SPoT), students' academic self-perception (SASP), students' perception of atmosphere (SPoA) and students' social self-perception (SSSP) $(13,41)$. Each item is rated based on five Likert-scales ranging between 0 and $4(0=$ strongly disagree, $1=$ disagree, $2=$ unsure, $3=$ agree and $4=$ strongly agree). There are 9 negative items that must be scored in a reverse manner prior to analysis and interpretation; item $4,8,9,17,25,35,39,48$ and 50 (Roff, et al., 1997).
The DREEM inventory has been translated into various languages and the reported overall Cronbach's alpha coefficient ranges between 0.89 and $0.93(3,12,15,16,18-20,30)$. Items with a mean score of 3.5 or more are true positive points. Items with a mean score of 2.0 or less should be examined more closely, as they indicate problem areas. Items with a mean between 2.0 and 3.0 are aspects of the educational environment that could be enhanced. The original version of DREEM was used in this study. The guidelines for interpreting the overall DREEM score are 0-50, very poor; 51-100, many problems; 101-150, more positive than negative; and 151-200, excellent (41). To indicate the different areas of the educational environment, the DREEM items are grouped into 5 subscales:

1. Students' Perception of Learning (SPoL) has 12 items, with a maximum score of 48 (satisfactory score $=24$ ).

2. Students' Perception of Teaching (SPoT) has 11 items, with a maximum score of 44 (satisfactory score $=22$ ).

3. Students' Academic Self-Perception (SASP) has 8 items, with a maximum score of 32 (satisfactory score $=16$ ).

4. Students' Perception of Atmosphere (SPoA) has 12 items, with a maximum score of 48 (satisfactory score $=24$ ).

5. Students' Social Self-Perception (SSSP) has 7 items, with a maximum score of 28 (satisfactory score $=14$ ).

\section{Result}

A total of $511(77.9 \%)$ respondents completed the 50 statements of the DREEM inventory. Most of them were female $(61.1 \%)$, third year (38.4\%) and Malay (52.1\%) medical students (table 1). 
Table 1: Demographic profile of participants

\begin{tabular}{|c|c|c|}
\hline Variables & & $\begin{array}{c}\text { Frequency }(\%) \\
(\mathrm{N}=511)\end{array}$ \\
\hline \multirow[t]{3}{*}{ Year of study } & First year & $156(30.5)$ \\
\hline & Third year & $196(38.4)$ \\
\hline & Fifth year & $159(31.1)$ \\
\hline \multirow[t]{3}{*}{ Sex } & Male & 175 (34.2) \\
\hline & Female & $312(61.1)$ \\
\hline & Missing data & $24(4.7)$ \\
\hline \multirow[t]{5}{*}{ Race } & Malay & $266(52.1)$ \\
\hline & Chinese & $170(33.3)$ \\
\hline & Indian & $43(8.4)$ \\
\hline & Other & $7(1.4)$ \\
\hline & Missing data & $25(4.9)$ \\
\hline
\end{tabular}

Table 2: Mean score of the 50 items of DREEM according to its domain.

\section{No. \& statement}

\section{Students' Perception of Learning (SPoL)}

Q1. I am encouraged to participate during teaching sessions

Q7. The teaching is often stimulating

Q13. The teaching is student-centred

Q16. The teaching helps to develop my competence

Q20. The teaching is well-focused

Q22. The teaching helps to develop my confidence

Q24. The teaching time is put to good use

Q25. The teaching over-emphasizes factual learning*

Q38. I'm clear about the learning objectives of the course

Q44. The teaching encourages me to be an active learner

Q47. Long-term learning is emphasized over short-term learning

Q48. The teaching is too teacher-centred*

Total mean score

Maximum score

\section{Students' Perception of Teachers (SPoT)}

Q2. The teachers are knowledgeable

Q6. The teachers adopt a patient-centred approach to consulting

Q8. The teachers ridicule the students*

Q9. The teachers are authoritarian*

Q18. The teachers have good communication skills with patients

Q29. The teachers are good at providing feedback to students

Q32. The teachers provide constructive criticism here

Q37. The teachers give clear examples

Q39. The teachers get angry in teaching*

Q40. The teachers are well-prepared for their teaching sessions

Q50. The students irritate the teachers*

Total mean score

Maximum score

\section{Students' Academic Self-Perception (SASP)}

Q5. Learning strategies that worked for me before continue to

work for me now

Q10. I am confident about my passing this year

Q21. I feel I am being well prepared for my profession

Q26. Last year's work has been a good preparation for this year's

work

Q27. I am able to memorize all I need

Q31. I have learnt a lot about empathy in my profession

\section{Mean (SD)}

Overall $\quad$ Year $1 \quad$ Year $3 \quad$ Year 5

$2.85(0.75)$

$2.78(0.84)$

$2.47(0.99)$

$3.00(0.80)$

$2.82(0.81)$

$2.68(0.89)$

$2.79(0.81)$

$1.34(0.83)$

$2.80(0.77)$

$2.86(0.74)$

$2.80(0.74)$

$2.01(0.95)$

31.18 (5.43)

48

$3.21(0.69)$

$2.81(0.83)$

$2.18(0.93)$

$1.90(0.90)$

$2.92(0.82)$

$2.61(0.87)$

$2.67(0.80)$

$2.77(0.75)$

$2.15(1.02)$

$2.74(0.82)$

$2.09(0.99)$

28.04 (4.94)

44

$2.63(0.85)$

$2.60(0.94)$

$2.55(0.92)$

$2.57(0.92)$

$1.89(1.00)$

$2.95(0.72)$
$3.09(0.73)$

$2.99(0.83)$

$2.91(0.82)$

$3.10(0.83)$

$3.11(0.70)$

$2.98(0.78)$

$3.05(0.73)$

$1.13(0.80)$

$3.00(0.70)$

3.03 (0.69)

$2.99(0.77)$

$1.96(1.07)$

33.33 (5.64)

48

$3.30(0.69)$

$2.95(0.83)$

$2.36(1.07)$

$2.03(0.97)$

$3.03(0.75)$

$3.00(0.72)$

$2.91(0.82)$

$3.02(0.67)$

$2.29(1.13)$

$3.05(0.73)$

2.33 (1.15)

30.28 (4.97)

44

$2.73(0.96)$

$2.58(0.83)$

$2.61(0.75)$

$2.81(0.96)$

$2.56(0.94)$

$2.44(0.87)$

$2.91(0.85)$

$2.18(0.90)$

$2.64(0.84)$

$2.81(0.83)$

$2.39(0.98)$

$2.57(0.87)$
$2.74(0.76) \quad 2.74(0.70)$

$2.61(0.83) \quad 2.80(0.83)$

$2.27(1.01)$

$2.61(0.87) \quad 2.79(0.74)$

$2.37(0.97) \quad 2.77(0.77)$

$2.73(0.77)$

$2.76(0.82) \quad 2.82(0.66)$

$2.82(0.66)$
$(0.62)$

$31.30(4.61)$ 48

$3.19(0.66)$

$2.89(0.77)$

$1.94(0.90)$

$1.84(0.92)$

$3.01(0.71)$

$2.54(0.82)$

$2.72(0.68)$

$2.81(0.68)$

$1.86(0.98)$

$2.77(0.73)$

$1.83(0.94)$

$27.42(4.24)$ 44 


\begin{tabular}{|c|c|c|c|c|}
\hline Q41. My problem-solving skills are being well developed here & $2.75(0.72)$ & $2.96(0.71)$ & $2.58(0.76)$ & $2.77(0.62)$ \\
\hline $\begin{array}{l}\text { Q45. Much of what I have to learn seems relevant to a career in } \\
\text { healthcare }\end{array}$ & $2.92(0.69)$ & $3.04(0.72)$ & $2.83(0.73)$ & $2.91(0.59)$ \\
\hline Total mean score & $20.87(4.49)$ & $22.59(4.90)$ & $19.64(4.19)$ & $20.68(3.87)$ \\
\hline Maximum score & 32 & 32 & 32 & 32 \\
\hline \multicolumn{5}{|l|}{ Students' Perception of Atmosphere (SPoA) } \\
\hline Q11. The atmosphere is relaxed during ward teaching & $2.23(1.05)$ & $2.81(0.83)$ & $1.93(1.06)$ & $2.03(1.01)$ \\
\hline Q12. This school is well time-tabled & $2.46(1.04)$ & $2.96(0.86)$ & $2.29(1.02)$ & $2.19(1.05)$ \\
\hline Q17. Cheating is a problem in this school* & $2.22(1.26)$ & $2.56(1.19)$ & $2.52(1.15)$ & $1.53(1.19)$ \\
\hline Q23. The atmosphere is relaxed during lectures & $2.74(0.85)$ & $2.99(0.79)$ & $2.66(0.85)$ & $2.61(0.88)$ \\
\hline $\begin{array}{l}\text { Q30. There are opportunities for me to develop my interpersonal } \\
\text { skills }\end{array}$ & $2.86(0.72)$ & $3.06(0.67)$ & $2.73(0.78)$ & $2.83(0.64)$ \\
\hline Q33. I feel comfortable in class socially & $2.85(0.73)$ & $3.00(0.75)$ & $2.72(0.78)$ & $2.86(0.64)$ \\
\hline Q34. The atmosphere is relaxed during class/s & $2.72(0.80)$ & $2.93(0.80)$ & $2.54(0.81)$ & $2.75(0.71)$ \\
\hline Q35. I find the experience disappointing* & $2.26(0.99)$ & $2.19(1.17)$ & $2.33(0.92)$ & $2.24(0.89)$ \\
\hline Q36. I am able to concentrate well & $2.69(0.78)$ & $2.87(0.77)$ & $2.56(0.81)$ & $2.68(0.74)$ \\
\hline Q42. The enjoyment outweighs the stress of the course & $2.49(0.89)$ & $2.87(0.74)$ & $2.28(0.93)$ & $2.38(0.87)$ \\
\hline Q43. The atmosphere motivates me as a learner & $2.84(0.70)$ & $3.04(0.66)$ & $2.73(0.73)$ & $2.79(0.65)$ \\
\hline Q49. I feel able to ask the questions I want & $2.58(0.91)$ & $2.94(0.78)$ & $2.30(0.94)$ & $2.59(0.87)$ \\
\hline Total mean score & $30.96(6.31)$ & $34.21(6.40)$ & $29.58(5.71)$ & $29.48(5.74)$ \\
\hline Maximum score & 48 & 48 & 48 & 48 \\
\hline \multicolumn{5}{|l|}{ Students' Social Self-Perception (SSSP) } \\
\hline Q3. There is a good support system for students who get stressed & $2.34(1.04)$ & $2.80(0.95)$ & $2.12(1.01)$ & $2.16(1.00)$ \\
\hline Q4. I am too tired to enjoy the course* & $2.23(1.09)$ & $2.37(1.11)$ & $2.27(1.05)$ & $2.04(1.08)$ \\
\hline Q14. I am rarely bored in this course & $2.00(1.16)$ & $2.17(1.24)$ & $1.88(1.14)$ & $1.99(1.07)$ \\
\hline Q15. I have good friends in this course & $3.15(0.84)$ & $3.18(0.79)$ & $3.16(0.85)$ & $3.10(0.88)$ \\
\hline Q19. My social life is good & $2.89(0.86)$ & $3.01(0.80)$ & $2.89(0.82)$ & $2.78(0.95)$ \\
\hline Q28. I seldom feel lonely & $2.31(1.02)$ & $2.53(1.00)$ & $2.21(1.07)$ & $2.21(0.95)$ \\
\hline Q46. My accommodation is pleasant & $2.39(1.10)$ & $2.47(1.22)$ & $2.35(1.03)$ & $2.35(1.06)$ \\
\hline Total mean score & $17.30(3.80)$ & $18.54(3.98)$ & $16.87(3.59)$ & $16.62(3.59)$ \\
\hline Maximum score & 28 & 28 & 28 & 28 \\
\hline Overall mean score $($ maximum $=\mathbf{2 0 0})$ & $\begin{array}{l}128.36 \\
(21.81)\end{array}$ & $\begin{array}{l}138.94 \\
(23.08)\end{array}$ & $\begin{array}{l}122.27 \\
(20.19)\end{array}$ & $\begin{array}{l}125.49 \\
(18.55)\end{array}$ \\
\hline
\end{tabular}

* Negative item Bold italic indicated areas of concerns

The analysis of the SPoL subscale (table 2) showed that the global scores for year 1 , year 3 and year 5 were 33.33/48, 29.4/33 and 31.3/48 respectively. Across the years of study, item 25 (the teaching over-emphasizes factual learning) consistently scored less than 2.00 , meaning that students agreed with the statement. At the preclinical years (i.e. year 1 and 3), item 48 (the teaching is too teacher-centred) scored less than 2.00 , indicating students agreed with the statement. In year 1, item 1 (I am encouraged to participate during teaching sessions), item 16 (the teaching helps to develop my competence), item 20 (the teaching is well-focused), item 24 (the teaching time is put to good use), and 44 (the teaching encourages me to be an active learner) scored more than 3.00, indicating the strengths of educational environment in the year 1.
The analysis of the SPoT subscale (table 2) showed that the global scores for year 1 , year 3 and year 5 were 30.28/44, 26.77/44 and 27.42/44 respectively. Across years of study, item 2 (the teachers are knowledgeable) consistently scored more than 3.00, indicating the strengths of educational environment in SMS. In the year 3 and 5, item 9 (the teachers are authoritarian) scored less than 2.00, indicating that as a whole the $3^{\text {rd }}$ and $5^{\text {th }}$ year medical students agreed with the statement. In the year 5 , item 8 (the teachers ridicule the students), item 39 (the teachers get angry in teaching) and item 50 (the students irritate the teachers) scored less than 2.00, indicating the year $5^{\text {th }}$ agreed with the statements. Item 18 (the teachers have good communication skills with patients) scored more than 3.00 by the $1^{\text {st }}$ and $5^{\text {th }}$ year students, indicating they perceived positively about teachers' communication skills with patients. 
Item 37 (the teachers give clear examples) and item 40 (the teachers are well-prepared for their teaching sessions) scored more than 3.00 by the $1^{\text {st }}$ year students, indicating the strengths of teachers in delivering teaching content. Overall, item 9 (the teachers are authoritarian) scored less than 2.00, indicating the weakness of educational environment in SMS in this aspect.

The analysis of SASP subscale (table 2) showed that the global score for year 1 , year 3 and year 5 were $22.59 / 32,19.64 / 32$ and 20.68 respectively. Overall, item 27 (I am able to memorize all I need) scored less than 2.00, indicating students disagreed with the statement. The item 27 also scored less than 2.00 in the year 3 and year 5 .

The analysis of SPoA subscale (table 2) showed that the global score for year 1 , year 3 and year 5 were $34.21 / 48, \quad 29.58 / 48$ and 25.48/48 respectively. Item 11 (the atmosphere is relaxed during ward teaching) scored less than 2.00 by the $3^{\text {rd }}$ year medical students, indicating they disagreed with the statement. Item 17 (cheating is a problem in this school) scored less than 2.00 by the $5^{\text {th }}$ year medical students, indicating they agreed with the statement.

The analysis of SSSP subscale (table 2) showed that the global score for year 1 , year 3 and year 5 were 18.54/28, $16.87 / 28$ and 16.62/28 respectively. Item 14 (I am rarely bored in this course) scored less than 2.00 by the $3^{\text {rd }}$ and $5^{\text {th }}$ year medical students, indicating that they were bored with this course.

The global scores for year 1 , year 3 and year 5 were $138.94 / 200,122.27 / 200$ and 125.49/200 respectively (table 2). The global scores indicate that across the years of study, educational environment at SMS were more positive than negative. The highest global score was in year 1 , followed by year 5 and year 3. There was a decreased pattern of educational environment throughout years of study.

The mean global score across the years of study was 128.36/200 (table 2), indicating that the educational environment at the School of Medical Sciences (SMS) were more positive than negative. The mean global score across the years of study for SPoL was 31.18/48; SPoT was $28.04 / 44$; SASP was $20.87 / 32$; SPoA was 30.96/48; and SSSP was 17.3/28. The students perceived educational environment positively for all 5 DREEM subscales. Across years of study, out of 50 statements, 2 items scored more than 3.00 (indicating the areas of strength), 45 items scored between 2.00 to 3.00 (indicating areas for improvement), and 3 items scored less than 2.00 (i.e. indicating areas of concern).

In summary, these results clearly showed an increasing number of areas of concern throughout different stages of medical training (table 3). The highest number of areas of concern was in the Year $5(n=8)$ and the lowest was in the Year $1 \quad(n=2)$ (table 3). There were three shared areas of concern that related to the teaching, teacher and students' learning ability (table 3). The highest number of strong areas was in Year $1(n=15)$ and the lowest was in Year 3 $(n=2)$ (table 4). There were two shared strong areas which were related to teacher and social support (table 4). 
Table 3: Specific and overall areas of concern (i.e. mean score less than 2.00) by years of study

\begin{tabular}{|c|c|c|c|}
\hline Year 1 & Year 3 & Year 5 & Overall \\
\hline $\begin{array}{l}\text { Q25. The teaching over- } \\
\text { emphasizes factual } \\
\text { learning* } \\
\text { Q48. The teaching is too } \\
\text { teacher-centred* }\end{array}$ & $\begin{array}{l}\text { Q25. The teaching over- } \\
\text { emphasizes factual learning* } \\
\text { Q48. The teaching is too } \\
\text { teacher-centred* } \\
\text { Q9. The teachers are } \\
\text { authoritarian* } \\
\text { Q27. I am able to memorize all } \\
\text { I need } \\
\text { Q11. The atmosphere is } \\
\text { relaxed during ward teaching } \\
\text { Q14. I am rarely bored in this } \\
\text { course }\end{array}$ & $\begin{array}{l}\text { Q25. The teaching over- } \\
\text { emphasizes factual learning* } \\
\text { Q8. The teachers ridicule the } \\
\text { students* } \\
\text { Q9. The teachers are } \\
\text { authoritarian* } \\
\text { Q39. The teachers get angry in } \\
\text { teaching* } \\
\text { Q50. The students irritate the } \\
\text { teachers* } \\
\text { Q27. I am able to memorize all } \\
\text { I need } \\
\text { Q17. Cheating is a problem in } \\
\text { this school* } \\
\text { Q14. I am rarely bored in this } \\
\text { course }\end{array}$ & $\begin{array}{l}\text { Q25. The teaching over- } \\
\text { emphasizes factual learning* } \\
\text { Q9. The teachers are } \\
\text { authoritarian* } \\
\text { Q27. I am able to memorize all } \\
\text { I need }\end{array}$ \\
\hline
\end{tabular}

* Negative item

Table 4: Specific and overall strong areas (i.e. mean score more than 3.00) by years of study

\begin{tabular}{|c|c|c|c|}
\hline Year 1 & Year 3 & Year 5 & Overall \\
\hline $\begin{array}{l}\text { Q1. I am encouraged to participate } \\
\text { during teaching sessions } \\
\text { Q16. The teaching helps to develop } \\
\text { my competence } \\
\text { Q20. The teaching is well-focused } \\
\text { Q24. The teaching time is put to good } \\
\text { use } \\
\text { Q44. The teaching encourages me to } \\
\text { be an active learner } \\
\text { Q2. The teachers are knowledgeable } \\
\text { Q18. The teachers have good } \\
\text { communication skills with patients } \\
\text { Q37. The teachers give clear examples } \\
\text { Q40. The teachers are well-prepared } \\
\text { for their teaching sessions } \\
\text { Q31. I have learnt a lot about empathy } \\
\text { in my profession } \\
\text { Q45. Much of what I have to learn } \\
\text { seems relevant to a career in healthcare } \\
\text { Q30. There are opportunities for me to } \\
\text { develop my interpersonal skills } \\
\text { Q43. The atmosphere motivates me as } \\
\text { a learner } \\
\text { Q15. I have good friends in this course } \\
\text { Q19. My social life is good }\end{array}$ & $\begin{array}{l}\text { Q2. The teachers are } \\
\text { knowledgeable } \\
\text { Q15. I have good friends } \\
\text { in this course }\end{array}$ & $\begin{array}{l}\text { Q16. The teaching helps to } \\
\text { develop my competence } \\
\text { Q2. The teachers are } \\
\text { knowledgeable } \\
\text { Q18. The teachers have } \\
\text { good communication skills } \\
\text { with patients } \\
\text { Q31. I have learnt a lot } \\
\text { about empathy in my } \\
\text { profession } \\
\text { Q15. I have good friends in } \\
\text { this course }\end{array}$ & $\begin{array}{l}\text { Q2. The teachers are } \\
\text { knowledgeable } \\
\text { Q15. I have good friends } \\
\text { in this course }\end{array}$ \\
\hline
\end{tabular}

\section{Discussion}

On the whole, the medical school was perceived by its students as having more positive than negative educational climate (the mean global score was 128/200). These results demonstrated that there were rooms for improvement if appropriate measures are taken by the medical school. Likewise, the educational climate in the medical school was comparable with other medical schools across the globe which was reported in literature to show global DREEM 
scores ranging from 89 to $143(9,11,12,14,21$ $35)$. In fact, the educational climate recorded in this study was better than the finding of a previous study that was conducted in the same medical school (i.e. 117.9/200) (8). As is observed in this study, there were three overall areas of concern which were the teaching overemphasizes factual learning, the teachers are authoritarian and difficulty in memorizing study subjects (table 3 ). These findings are consistent with several previous studies $(8,9,11,23,24$, 26, 27). Two lessons can be learnt from these findings. First, the medical school should look carefully at the potential overlapping of content across phases of study. This is to ensure that the students are not overloaded with unnecessary and irrelevant information. It should be highlighted that previous studies reported that one of the major stressors for medical students were too much content to be learnt within limited time (42-44). Perhaps a proper rearrangement of medical curricula content across phases of study during the curriculum review may produce beneficial impacts on the medical students' learning ability. Likewise it may buffer the unwanted impact of medical education on medical students' wellbeing $(44,45)$. Second, the medical school should perhaps design a module through a series of faculty development workshops that could train and certify its faculty members on basic competencies of teaching and learning in medical education. Faculty development is the key to improve quality of medical teachers in the art and science teaching and learning (46) leading to improvement of the overall educational climate.

Apart from that, there were two overall areas of strength which were: the medical teachers are expert in their field and the medical students have a good relationship with their peers (table 4). These results indicated that the faculty members in the medical school are the content experts in the field and the social relationships between students are in a healthy state. These findings are consistent with previous studies (7, $11,27,30)$. It is worth to mention that a student who feels well supported is less likely to experience burnout and psychological distress thus leading to a better learning experience (43, $47,48)$.

Our results showed that each phase of medical training had its own strengths and weaknesses. In general, based on the global DREEM score it appeared that the lowest score was in the paraclinical phase (122/200) and the highest was in the pre-clinical phase (139/200). Even so, all phases of medical training showed more positive than negative educational climates. This finding suggests that there are plenty of rooms for improvement for each phase. In addition, our results clearly showed that the number of weaknesses was more apparent in the clinical phase, while the number of strengths was more apparent in the pre-clinical phases (table 3 and table 4). Likewise, previous studies found similar pattern of educational climate in their institutions $(24,27,29)$. These facts suggested that our medical school's educational climate is comparable with other medical schools' educational environment. In fact, our educational climate at the pre-clinical phase is better than the reported figures from previous studies that ranged between 96.5 and 130 for a similar phase of a medical programme $(24,26-$ 29).

The unique weaknesses at the clinical phase were 'the teachers ridicule the students', 'the teachers get angry in teaching', 'the students irritate the teachers' and 'cheating is a problem in this school'. It reflected that the medical students perceived they were poorly treated during teaching sessions and they had a concern about academic dishonesty among their peers. Quite a number of studies reported that medical students at clinical phase felt that they were poorly treated by teachers during teaching sessions $(9,24,28)$. Likewise, several studies reported that academic dishonesty among medical students in clinical phase was an area of concern $(9,30)$. In contrast, a few studies did not report academic dishonesty among their students $(24,28)$ as well as their students felt being poorly treated during teaching session (25-27) as problematic areas in their institution An interesting finding from a previous study reported that under-achiever students significantly had higher concerns about cheating 
as a problem in medical school as compared to high-achiever students in the clinical phase (23). One important lesson is that the medical school should look into these issues carefully to avoid unnecessary induction of emotional and psychological pressures to the medical students. A unique weakness at the pre-clinical and paraclinical phases was 'the teaching is too teachercentred'. Similar problem was reported by previous studies $(8,24)$. Interestingly, the paraclinical phase in the medical school is mainly conducted in a problem based learning (PBL) approach, yet the students still perceived the educational process as more teacher-centered. One implication is that the medical school should look carefully at the implementation of the PBL sessions because poor implementation of $\mathrm{PBL}$ may lead to teacher-centered rather than studentcentered learning.

The only unique weakness at the para-clinical and clinical phases was the students felt bored in these phases. Similar finding was reported by previous studies $(8,24,26,27,30)$. This is another interesting finding because these two phases should be enjoyable phases for medical students because most of the learning would be self-directed and tuned toward clinical application, but surprisingly they perceived it as a dull phase. The authors believe that the curriculum review committee must really look carefully on these issues because it may lead to unproductive learning experience among the students. It is worthy to highlight that for effective learning to occur, a learner must have a desire to learn, without which effective learning would not occur (49).

The unique strengths in the pre-clinical phase were related to the teachers' quality (the teaching is well-focused', 'the teaching time is put to good use, 'the teaching encourages me to be an active learner', 'I am encouraged to participate during teaching sessions', 'the teachers give clear examples', 'the teachers are well-prepared for their teaching sessions'), healthy atmosphere for learning ('much of what I have to learn seems relevant to a career in healthcare', 'there are opportunities for me to develop my interpersonal skills', 'the atmosphere motivates me as a learner'), and a healthy social status ('my social life is good'). These facts suggested that the medical teachers who were teaching in the preclinical phase provided a high quality of teaching and learning experience to the students. Perhaps the medical school should find ways to ensure such teaching qualities could be sustained throughout the phases of medical training.

The unique strengths at the pre-clinical and clinical phases were 'the teachers have good communication skills with patients', 'I have learnt a lot about empathy in my profession', and 'the teaching helps to develop my competence'. These facts indicated that while imparting knowledge, the teachers had also shown a good role-model to promote development of positive personal quality among the medical students across phases of medical training. It is worthy to highlight that the professional behaviour is an important area of medical education that has been long concern to medical educators (50).

In summary, based on the findings discussed previously, the authors believe that: 1) the medical school has reasonably level of educational climates across phases of medical training; 2) the medical teachers are knowledgeable and well prepared for the teaching; 3) the students were overloaded with factual knowledge; 4) the medical teachers are quite harsh to students during teaching session especially in clinical phase; 5) students experienced a significant amount of stress that lead to poor memory; 6) the educational process was inclined toward teacher-centered rather than student-centered learning ; 7) students had a considerable healthy social relationships with peers as well as others; and 8) academic dishonesty became more apparent in the clinical phase which might need to be addressed carefully. Based on these findings the medical school should organize regular faculty development activities to address issues on teacher-centered versus student-centered learning, academic dishonesty among medical students, over-emphasis on factual learning over understanding, best practices in clinical teaching, facilitating PBL, and helping students cope with 
difficulty in learning. These areas should be addressed during the curriculum review process.

\section{Conclusion}

The medical school's educational environment across different phases of study was more positive than negative. However, there are plenty of rooms for improvement as perceived by the medical students. The medical school should address various important issues highlighted in this article during the curriculum review process.

\section{Acknowledgement}

Our deepest appreciation to all medical students who participated in this study voluntarily as well as staff from the academic office who help us in preparation of the questionnaire.

\section{Reference}

1. Dent JA, Harden RM. A practical guide for medical teachers. 3rd ed: Elsevier Churchill Livingstone; 2009.

2. Newble D, Cannon RA, Kapelis ZA. A handbook for medical teachers: Kluwer Academic Publishers; 2001.

3. Yusoff MSB. The Dundee Ready Educational Environment Measure: A Confirmatory Factor Analysis in a Sample of Malaysian Medical Students. International Journal of Humanities and Social Science 2012;2(16):313-21.

4. Genn J. AMEE Medical Education Guide No. 23 (Part 1): Curriculum, environment, climate, quality and change in medical education - a unifying perspective. Medical Teacher. 2001;23(4):337-44.

5. Genn J. AMEE Medical Education Guide No. 23 (Part 2): Curriculum, environment, climate, quality and change in medical education - a unifying perspective. Medical Teacher. 2001;23(5):445-54.

6. Audin K, Davy J, Barkham M. University Quality of Life and Learning (UNIQoLL): An approach to student well-being, satisfaction and institutional change. Journal of Further and Higher Education. 2003;27(4):365-82.

7. Whittle S, Whelan B, Murdoch-Eaton D. DREEM and beyond; studies of the educational environment as a means for its enhancement. Education for Health. 2007;20(1):1-9.

8. Arzuman H, Yusoff MSB, Chit SP. Big Sib Students' Perceptions of the Educational Environment at the School of Medical Sciences, Universiti Sains Malaysia, using Dundee Ready Educational Environment Measure (DREEM) Inventory. Malaysian Journal of Medical Sciences. 2010;17(3):407.

9. Al-Hazimi A, Al-Hyiani A, Roff S. Perceptions of the educational environment of the medical school in King Abdul Aziz University, Saudi Arabia. Medical Teacher. 2004;26(6):570-3.

10. Al-Hazimi A, Zaini R, Al-Hyiani A, Hassan $\mathrm{N}$, Gunaid A, Ponnamperuma $\mathrm{G}$, et al. Educational environment in traditional and innovative medical schools: A study in four undergraduate medical schools. Education for Health. 2004;17(2):192-203.

11. Said NM, Rogayah J, Arzuman H. A study of learning environments in the Kulliyyah (Faculty) of Nursing, International Islamic University Malaysia. Malaysian Journal of Medical Sciences. 2009;16(4):15-24.

12. Thomas BS, Abraham RR, Alexander M, Ramnarayan K. Students' perceptions regarding educational environment in an Indian dental school. Medical Teacher. 2009;31(5):185-8.

13. Roff S, McAleer S, Harden RM, Al-Qahtani M, Ahmed AU, Deza H, et al. Development and validation of the Dundee ready education environment measure (DREEM). Medical Teacher. 1997;19(4):295-9.

14. Varma R, Tiyagi E, Gupta J. Determining the quality of educational climate across multiple undergraduate teaching sites using the DREEM inventory. BMC Medical Education. 2005;5(1):8.

15. Yusoff MSB. Stability of DREEM in a Sample of Medical Students: A Prospective Study. Education Research International. 2012;2012:5

16. Yusoff MSB. Psychometric properties of DREEM in a sample of Malaysian medical students. Medical Teacher. 2012;34(7):5956.

17. Riquelme A, Oporto M, Oporto J, Mendez JI, Viviani P, Salech F, et al. Measuring students' perceptions of the educational climate of the new curriculum at the Pontificia Universidad Catalica de Chile: performance of the Spanish translation of the Dundee Ready Education Environment 
Measure (DREEM). Education for health (Abingdon, England). 2009;22(1):112.

18. Dimoliatis I, Vasilaki E, Anastassopoulos P, Ioannidis J, Roff S. Validation of the Greek translation of the Dundee ready education environment measure (DREEM). Education for Health. 2010;23(1):348.

19. Jakobsson U, Danielsen N, Edgren G. Psychometric evaluation of the Dundee Ready Educational Environment Measure: Swedish version. Medical Teacher. 2011;33(5):267-74.

20. Hammond SM, O'Rourke M, Kelly M, Bennett D, O'Flynn S. A psychometric appraisal of the DREEM. BMC Medical Education. 2012;12(1):2.

21. Zamzuri A, Ali A, Roff S, McAleer S. Students perceptions of the educational environment at dental training college. Malaysian Dent J. 2004;25:15-26.

22. Lai N, Nalliah S, Jutti R, Hla Y, Lim V. The educational environment and self-perceived clinical competence of senior medical students in a Malaysian medical school. Educ Health. 2009;22(2):1-15.

23. Mayya S, Roff S. Students' perceptions of educational environment: a comparison of academic achievers and under-achievers at Kasturba Medical College, India. Education for Health. 2004;17(3):280-91.

24. Abraham R, Ramnarayan K, Vinod P, Torke S. Students' perceptions of learning environment in an Indian medical school. BMC Medical Education. 2008;8(1):1-5.

25. Roff S, McAleer S, Ifere O, Bhattacharya S. A global diagnostic tool for measuring educational environment: comparing Nigeria and Nepal. Medical Teacher. 2001;23(4):378-82.

26. Jiffry $M$, McAleer S, Fernando S, Marasinghe $R$. Using the DREEM questionnaire to gather baseline information on an evolving medical school in Sri Lanka. Medical Teacher. 2005;27(4):348-52.

27. Demirören M, Palaoglu Ö, Kemahli S, Özyurda F, Ayhan I. Perceptions of Students in Different Phases of Medical Education of Educational Environment: Ankara University Faculty of Medicine. Medical education online. 2008;13(8):1-8.

28. Bassaw B, Roff S, McAleer S, Roopnarinesingh S, De Lisle J, Teelucksingh $\mathrm{S}$, et al. Students' perspectives on the educational environment, Faculty of Medical Sciences, Trinidad. Medical Teacher. 2003;25(5):522-6.
29. Al-Ayed I, Sheik S. Assessment of the educational environment at the College of Medicine of King Saud University, Riyadh. East Mediterr Health J. 2008;14(4):953-9.

30. Riquelme A, Oporto M, Oporto J, Mendez JI, Viviani P, Salech F, et al. Measuring students' perceptions of the educational climate of the new curriculum at the Pontificia Universidad Catalica de Chile: performance of the Spanish translation of the Dundee Ready Education Environment Measure (DREEM). Education for Health. 2009;22(1):112.

31. Denz-Penhey H, Murdoch JC. A comparison between findings from the DREEM questionnaire and that from qualitative interviews. Medical Teacher. 2009;31(10):449-53.

32. Tontuş HO. DREEM; dreams of the educational environment as its effect on education result of 11 Medical Faculties of Turkey. Journal of Experimental and Clinical Medicine. 2010;27(3):104-8.

33. Al-Hazimi A, Zaini R, Al-Hyiani A, Hassan N, Gunaid A, Ponnamperuma G, et al. Educational environment in traditional and innovative medical schools: A study in four undergraduate medical schools. Education for Health. 2004;17(2):192-203.

34. Al-Kabbaa AF, Ahmad HH, Saeed AA, Abdalla AM, Mustafa AA. Perception of the learning environment by students in a new medical school in Saudi Arabia: Areas of concern. Journal of Taibah University Medical Sciences. 2012.

35. Brown T, Williams B, Lynch M. The Australian DREEM: evaluating student perceptions of academic learning environments within eight health science courses. International Journal of Medical Education. 2011;2(1):94-101.

36. Zabidi H, Fuad A. Medical education in Universiti Sains Malaysia. The Medical Journal of Malaysia. 2002;57(Suppl E):8-12.

37. Azila NMA, Rogayah J, Zabidi-Hussin ZAMH. Curricular trends in Malaysian medical schools: innovations within. Ann Acad Med Singapore. 2006;35(9):647-54.

38. Yusoff MSB, Abdul Rahim AF, Rahman Noor A, Yaacob NA, Mohd Hussin ZA. Evaluation of medical students' perception towards the BigSib Programme in the School of Medical Sciences, USM. Education in Medicine Journal. 2010;2(1):e2-11.

39. Yusoff MSB, Esa AR, Mat Pa MN, See CM, Abdul Aziz R, Abdul Rahim AF. A 
longitudinal study of relationships between previous academic achievement, emotional intelligence and personality traits with psychological health of medical students during stressful periods. Education for Health. in press.

40. Roff S, McAleer S. What is educational climate? Medical Teacher. 2001;23(4):333.

41. McAleer S, Roff S. A practical guide to using the Dundee Ready Education Environment Measure (DREEM). AMEE Medical Education Guide. 2001(23):29-33.

42. Yusoff MSB, Rahim AFA. Prevalence and Sources of Stress among Postgraduate medical Trainees: Initial findings. Asean Journal of Psychiatry. 2010;11(2).

43. Yusoff MSB, Ahmad Hamid AH, Rosli NR, Zakaria NA, Che Rameli NA, Abdul Rahman NS, et al. Prevalence of stress, stressors and coping strategies among secondary school students in Kota Bharu, Kelantan, Malaysia. International Journal of Students' Research. 2011;1(1):23-8.

44. Dyrbye LN, Thomas MR, Shanafelt TD. Medical student distress: causes, consequences, and proposed solutions. Mayo Clinic Proc. 2005;80(12):1613-22.

45. Yusoff MSB, Abdul Rahim AF, Baba AA, Ismail SB, Mat Pa MN, Esa AR. The impact of medical education on psychological health of students: A cohort study. Psychology, Health \& Medicine [serial on the Internet]. 2012.

46. Ja'afar R. Two decades of championing faculty development: Is it worth the effort? Education in Medicine Journal. 2012;4(2):e1-6.

47. Payne R, Fletcher B. Job demands, supports, and constraints as predictors of psychological strain among school teachers. Journal of Vocational Behavior. 1983;22(2):136-47.

48. Brissie JS, Hoover-Dempsey KV, Bassler OC. Individual, situational contributors to teacher burnout. The Journal of Educational Research. 1988:106-12.

49. Williams GC, Deci EL. Internalization of biopsychosocial values by medical students: a test of self-determination theory. Journal of Personality and Social Psychology; Journal of Personality and Social Psychology. 1996;70(4):767-79.

50. Yusoff MSB. Professional Behaviour: What Does It Means? Education in Medicine Journal. 2009;1(1):1-5. 